\title{
ПОХОДЖЕННЯ УКРАЇНСЬКОЇ РІЗДВЯНОЇ ДРАМИ
}

\begin{abstract}
У статті розкриваються джерела украӥнської різдвяної драми XVII-XVIII ст., яка зайняла помітне місие в історії давньої літератури. До периорядних джерел віднесено середньовічну літургійну драму, основною формою якої була містерія. У різдвяному ичиклі найдавніших містерій домінують події, які добре надаються для театралізації, тобто мають дійових осіб, розвиток дії, наявність конфліктної ситуачії. Спираючись на євангельський текст, містерія не мала на меті його проілюструвати, а підкорялася правилам інсценізації, внаслідок чого хоч $і$ зберігалася основна сюжетна канва, однак додавалися нові тексти (наприклад, монологи волхвів, Ірода, пророків), а окремі сюжетні лінії могли увиразнюватися або відходити на другий план. У містерійних творах розігрувався різдвяний сюжет, почерпнутий із Євангелія. Він добре надавався для інсиенізації. У изьому переконує приклад, наведений у статті: різдвяна декламація Памви Беринди (1616 р.), яка являє собою периу творчу обробку матеріалу, щзо входив до складу старовинної європейської різдвяної містерії. Пролог у изьому творі насичений загальними фразами й патетикою з приводу різдвяного свята. Більше уваги приділено поклонінню новонародженому Ісусу, причому в декламації змішано інформацію, яку подають Матвій $і$ Лука. Надалі дійовими особами біля печери з яслами стають лише пастухи, які тут виступають як «самовидиі» чудесної події. Такий прийом оповіді дозволяє авторам декламації «наблизити» давню подію до своїх сучасників, які слухають проголошувану декламацію, оживити в їхній уяві священний час народження Сина Божого й перше воздання йому почестей. Загалом иңю декламаџію можна було б визначити як літературну варіацію на різдвяну тему, в якій євангельський сюжет лише означується через окремі епізоди, а весь текст становить собою патетичне розгортання радості від різдяяного свята. Інакше кажучи, маємо літературну обробку традиційної теми, запозиченої з Свангелія, але трансформованої в жанр декламаџіï за художніми приписами середньовічної драми. Отюе, $\epsilon$ підстави стверджувати, щуо українська різдвяна драма походить від середньовічних містерій.
\end{abstract}

Ключові слова: драма, містерія, Свангеліє, різдвяний сюжет, декламація.

Oksana SAVENKO, orcid.org/0000-0002-0117-0103

Candidate of Philological Sciences,

Associate Professor at the Department of Ukrainian and Foreign Literature Zhytomyr Ivan Franko State University (Zhytomyr, Ukraine)bpv1953@ukr.net

\section{THE ORIGIN OF THE UKRAINIAN CHRISTMAS DRAMA}

The main aim of the article is to reveal the sources of the Ukrainian drama of XVII-XVIII centuries, which has a prominent place in the history of the ancient literature. The medieval liturgical drama is belonged to primary sources, the main form of it was mystery. In the Christmas cycle of ancient mysteries all events are well provided for theatrical, they have actors, development steps, the presence of conflict. Leaning against an evangelic phototypograph a mystery did not have for an object to illustrate it, but submitted the rules of inscenization, a basic with a plot canvas was though kept as a result, new phototypographs (for example, monologues of magus, Irod, prophets) were however added and separate with a plot lines could be done distinctly or moved aside on the second plan. Religious drama was cultivated foremost in of that time colleges, seminaries and academies (school drama), and instrumental in strengthening of faith of young people, not only agitating but also adding criticism of apostates, threatening various punishment heretics. Similarly, the Easter mystery is developing, a key episode in which is the act of visiting the tomb of the deceased Jesus. The immediate source of ancient Ukrainian drama was Jesuit drama that learned medieval traditions, including artistic and ideological practices mysteries. So the play had a strong moral influence, can turn thoughts and feelings of the spectators in the direction in which the authors insisted. Jesuit practice has produced such dramatic forms, dialogues, drama performances with grand ceremonial occasions. Subjects were predominantly Christmas and Easter ones. From that begins of the Ukrainian drama, which convinces example given in the article: Christmas rant by Pamva Berynda (1616), which is the first creative process material that was part of the old European Christmas mystery. Overall this recitation can be defined as a literary variation on the theme of Christmas, which is defined Gospel story only through individual episodes and entire text is 
a pathetic deployment joy of the Christmas holiday. This declamation can it would be defined as literary variation on a Christmas theme, in which an evangelic subject is only designated through separate episodes, and all text is passionate development of gladness from a Christmas holiday. Speech goes about literary treatment of traditional theme, adopted from Gospel, but the declamation transformed in a genre after the artistic orders of medieval drama.

Key words: drama, mystery, medieval drama, Jesuit drama, Christmas story, the Easter story, Gospel rant.

Постановка проблеми. Джерела давньої драми - в середньовічній системі літургії (богослужіння), яка остаточно сформувалася в кінці першого тисячоліття. Середньовіччю загалом була властива театральність - побуту, етикету, лицарських турнірів, громадської практики в таких формах iï вираження, як посвята, ініціація, торгова оборудка. Католицький культ у західній церкві взяв на себе оформлення соціальних завдань, як то було раніше 3 античною драмою. Драматичні літургійні сюжети, почерпнуті зі Святого Письма, були цілком самодостатніми, тому без усякої потуги ділилися на окремі епізоди, мали такі драматичні компоненти, як перипетія, перелом, катастрофа, апофеоз, тож уже тут були закладені можливості переходу від ритуалу до драми. Цей процес відбувся в XI-XIII ст. Літургійна драма набула жанрових форм містерії (грецьк. mysterion - таємниия, таїнство, обряд) - так назвали середньовічну європейську драму XIV-XVI ст. Основними формами містерій були різдвяні й великодні драми, в яких розігрувалися відповідні євангельські сюжети. 3 різдвяного циклу відомі такі містерії: «Дійство про пастирів віфлеємських», «Дійство про волхвів», «Дійство про побиття немовлят», «Дійство про пророків» (Андреев, 1989: 91-137). Виникнення української різдвяної драми у зв'язку з функціонуванням середньовічних містерій єзуїтського типу в літературознавстві вивчалося не досить, тому існує потреба заглибитися в цю проблему.

Аналіз наукових досліджень. Українська драматургія в ії загальних аспектах (зміст, текстологічні питання, образи, театральна техніка й інше) була предметом вивчення В. Рєзанова, Я. Гординського, О. Білецького, М. Возняка, I. Франка, М. Сулими, проте походження української драми спеціально не досліджувалося.

У різдвяному циклі найдавніших містерій домінують події, які добре надаються для театралізації, тобто мають дійових осіб, розвиток дії, наявність конфліктної ситуації. Спираючись на євангельський текст, містерія не мала на меті його проілюструвати, а підкорялася правилам інсценізації, внаслідок чого хоч і зберігалася основна сюжетна канва, однак додавалися нові тексти (наприклад, монологи волхвів, Ірода, пророків), а окремі сюжетні лінії могли увиразню- ватися або відходити на другий план. Різдвяне дійство уже в середньовічній містерії відходило від канонічного ритуалу: по-перше, воно вивільнялося від євангельської послідовності, про що свідчать певні зміщення - поклоніння пастухів збігалося 3 поклонінням волхвів, побиття немовлят у Віфлеємі передувало поклонінню волхвів; по-друге, з дійства зникала описовість, а натомість 3'являлися діалоги біля ясел пастухів і волхвів, плач Рахілі тощо. Автори містерій не тільки літературно обробляли євангельський текст, а й пропонували певну драматичну концепцію. Дійство розпадалося на дві частини. У першій, яка закінчувалася сценою народження Ісуса, домінує тема непорочності. Друга частина - поява волхвів (пастухів) - уже не догматична, не віросповідальна, а політична - це тема влади, яка розігрується через постать Ірода (протиставлення «земного» царя справжньому - Ісусу Христу); автори змушують Ірода померти до того, як Ісус повернувся в Юдею.

Мета і завдання - виявити джерела давньої української драматургії, які, за припущенням автора, заховані в специфіці європейської середньовічної містерії.

Виклад основного матеріалу. Окремим різновидом шкільної європейської драми XVI ст. була єзуїтська драма (єзуїти - католицький орден, який сприяв зміцненню папства й католицизму, активно й організовано боровся з Реформацією). Як зазначали у своїх дослідженнях В. Рєзанов, М. Возняк, О. Білецький, постановки єзуїтських драм справляли велике естетичне враження на глядачів як своїм змістом, так і вмілим зображенням характерів, настроїв, ситуацій, дійових осіб, сценічними ефектами, коли застосовувались музика, малюнки, оптика, механіка. Отже, вистави мали сильний моральний вплив, могли повернути думку й почуття глядачів у тому напрямі, на якому автори наполягали. Єзуїтська практика виробила такі драматичні форми: діалоги, драми, парадні вистави з урочистих нагод. За тематикою це були переважно твори різдвяні й великодні.

Єзуїтська драма набула значного поширення в Польщі вже в другій половині XVI ст. Вона не обмежувалася тільки шкільною практикою, що звужувало іiі вплив, а виходила на вулиці й майдани, стала видовищем. Ось як О. Білецький зображує цю практику: «У ці дні по вули- 
цях Кракова або Вільна тягнуться колісниці, задрапіровані й прикрашені квітами й написами; на колісницях - постаті, що алегорично зображають Любов, Милосердя, святу Свхаристію тощо; за колісницями почет із піших і кінних школярів, що одягнені ангелами, рицарями, патріархами, пророками й співають гімни під акомпанемент оркестру. Процесія рухається до площі, де буде розіграно драматичну сцену на тему згадуваної події, а потім процесія повертається до храму, звідки вона вирушила. Легко уявити собі, яке враження на натовп справляли ці колісниці, ці тріумфальні арки 3 емблемами й гербами, зображення знарядь тортур і страти Христової, химерні костюми виконавців і виголошувані ними пишномовні вірші - все це масове дійство просто неба в руках єзуїтів було могутнім засобом пропаганди» (Білецький, 1965: 302-303).

Про польський єзуїтський театр згадано тому, що саме він мав безпосередній вплив на виникнення драматичного мистецтва в Україні. Про нього $є$ згадки в Івана Вишенського, котрий із позицій православної людини писав про нього досить критично: «А латинских басней ученицы зовемые казнодіи, трудитися в церкви не хочют, толко комедии строят и играют» (Вишенський, 1988: 314). У «Пораді» письменник веде мову про латинські «прелесті», до яких відносив і латинську мову, й освіту в єзуїтських колегіумах, і Арістотеля та Платона, й «комедії та машкари», тобто всю систему західної культури й освіти, яка йому уявлялася синонімом «зіпсуття, невіри, деморалізації та фальшивості» (І. Франко).

Такі настрої були й в інших православних діячів освіти й культури, котрі прагнули протиставити єзуїтським «машкарам» свої драматичні вистави, що плекалися в православних навчальних закладах уже наприкінці XVI ст., зокрема у Львівській братській школі, заснованій 1586 р. Парадоксально, але в новоутворених православних школах творилися та ставилися драматичні дійства, які (передусім у художній формі) повторювали єзуїтську практику. 3 цього приводу В. Рєзанов писав: «Українські братські школи мали науково виховати своїх учнів у дусі православія і тим певною мірою обмежити мандрівки української молоді «по світу» до шкіл польських і західноєвропейських <..> Щоб піднести свою школу до рівня католицької та щодо деталей, керівники навчальної справи намагалися були запровадити в побут учнів особливості, що приваблювали в школах інших вір: упорядковано виступи учнів із релігійно-драматичними декламаціями й співами в школі, в церкві й по інших місцях» (Рєзанов, 1926: 19).
Різдвяні й великодні декламації та діалоги були первинними формами давньої української драматургії. Вони писалися в тогочасних школах як навчальні вправи до курсу поетики з нагоди різдвяних і великодніх свят.

3 відомих нині декламацій найранішою $\epsilon$ віршова композиція «На рождество Господа Бога и Спаса нашого Ісуса Христа вършђ для утьхи православным христіаном» Памви Беринди, написана книжною українською мовою та видана у Львівській братській друкарні 1616 р. В. Рєзанов вважав, що цей твір являє собою творчу обробку матеріалу, що входив до складу старовинної європейської різдвяної містерії (Рєзанов, 1926: 20).

Пролог у цьому творі не становить собою «обробку матеріалу», оскільки насичений загальними фразами й патетикою з приводу різдвяного свята. Власне, обробка євангельського сюжету розпочинається з монологу «второго отрока», котрий веде мову про Віфлеєм, де у вертепі-печері народився Ісус. Народження Ісуса подається як чудо («о чудо, над всђх дивне зъ въку дивнђйшее»), уявлення про яке зображується за допомогою вдалого для цього художнього засобу - контрасту: «Того маленькій живот панєнскій змъщаєт / И вертеп такъ нендзный телєсне огортаєт» (Рєзанов, 1926: арк. 3).

Більше уваги приділено поклонінню новонародженому Ісусу, причому в декламації змішано інформацію, яку подають Матвій і Лука, бо говориться про те, що до вертепу прийшли поклонитися «кролеве перскіє с подарки» (так у Матвія), і водночас «пастухове» (так у Луки). Надалі дійовими особами біля печери 3 яслами стають лише пастухи, які тут виступають як «самовидці» чудесної події. Такий прийом оповіді дозволяє авторам декламації «наблизити» давню подію до своїх сучасників, які слухають проголошувану декламацію, оживити в їхній уяві священний час народження Сина Божого й перше воздання йому почестей. П'ятий «отрок» із цією метою подає себе перед слухачами як очевидець того, що відбулося у Віфлеємі: «Вправдъ я єсть, который то зъ ними [пастухами] былем по том, / То єсть по нароженю збавителя святом. / Справу ми ни такую о речах дали, / Которую въ Вифлеємъ очне оглядали» (Рєзанов, 1926: арк. 4 зв.). Домислом, почерпнутим швидше за все з поширюваних в Галичині апокрифів, можна визначити «речь» пастухів, яку передає «отрок», однак він твердо спирається на сюжетну основу, викладену в Свангелії від Луки (Лк. 2, 8:20): вночі пастухи вартували свою отару, та ось до них явився архангел Гавриїл, котрий сповістив про народження Христоса - «збавителя, всего 
свђта 3 неволъ клятвы откупителя» (слова Гавриїла передано близько до тексту Свангелія); майже дослівно йдеться про «небесне військо», яке тут назване «рицарством небесним»; коли ангели відійшли, пастухи подалися до Віфлеєма, де виявили Марію, Йосипа й сповите Дитятко в яслах, як і провістив архангел. А от далі бачимо відхилення від книги Луки, й полягає воно у внесенні до тексту декламації вітальної промови пастухів до Ісуса: «Царю несмертельный, всьх речій створителю, / Пане, створенья свого откупителю, / Котрыйсь рачил на ся тьло тоє прийняти / И непріятелеви съ пащеки отнятии / Чловька, котрого ты сам створити рачил / И упадку єго до конца не передбачил!» (Рєзанов, 1926: арк. 5). У цьому звертанні заховані алюзії на Старий Завіт, в якому йдеться про сотворіння світу (тут це приписується Христові), створення людини, яка вийшла недосконалою, бо согрішила, тому для порятунку гріховного люду прийшов у світ Ісус. Як видно, в лаконічному звертанні сконцентрована значна біблійна інформація, яка не розкривається повністю, оскільки автори передбачають, що вона відома слухачам, яким варто лише на неї натякнути.

Закінчується звернення до Христа й далі вставляється вітальна промова до «матки» (Богородиці), яку названо «пренайчистішою» та якій воздається хвала за те, що вона «породила всего свђта збав- леньє», а потім - до Йосипа, «слуги невимовного Його народження». Після цього уявні пастухи 3 відповідною та короткою промовою звертаються до неживих предметів - до ясел, «в которых лежит повитый творець серафімскій», до вертепу, який називається «коштовним палацом». Зрештою, пастухи промовляють і до Віфлеєма, «святої країни», «отчизни Христа». Закінчується монолог п'ятого «отрока» картиною загальної радості від того, що узріли пастухи у Віфлеємі: «И преч юж отшедши почали мы спЊвати, / И з радости оноє гойне выскакати. / Презъ поле до стад своих що в скок ся маючи, / В пищалки весело собђ заграваючи» (Рєзанов, 1926: арк. 5 зв.). Думається, що зображенням цієї радості, про яку не йдеться в жодному 3 Євангелій, автори декламації прагнули створити святковий настрій, передати його слухачам.

Висновки. Загалом цю декламацію можна було б визначити як літературну варіацію на різдвяну тему, в якій євангельський сюжет лише означується через окремі епізоди, а весь текст становить собою патетичне розгортання радості від різдвяного свята. Інакше кажучи, маємо літературну обробку традиційної теми, запозиченої з Євангелія, але трансформованої в жанр декламації за художніми приписами середньовічної драми. Отже, можемо підсумувати, що українська різдвяна драма походить від середньовічних містерій.

\section{СПИСОК ВИКОРИСТАНИХ ДЖЕРЕЛ}

1. Андреев М. Средневековая европейская драма: происхождение и становление (X-XIII вв.). Москва, 1989. 215 с.

2. Білецький О. Зародження драматичної літератури в Україні. Зібрання пращь : у п’яти томах / О. Білецький. Т. 1. Київ, 1965. С. 277-353.

3. Вишенський I. Книжка (глава 3). Украӥнська література XIV-XVI cm. Київ, 1988. С. 311-315.

4. Возняк М. Історія української літератури : у 2 кн. Кн. 2. Львів, 1994. 555 с.

5. Рєзанов В. Драма українська. Старовинний театр український. Вип. 1. Київ, 1926. 203 с.

\section{REFERENCES}

1. Andreev M. Srednevekovaia evropeiskaia drama: proyskhozhdenye i stanovlenie [Medieval European drama: origin and formation], M., 1989 [In Russian].

2. Biletskyi O. Zarodzhennia dramatychoi Literaturi v Ukraini [The birth of dramatic Literature in Ukraine]. Zidrannia prats, Nr. 1. K.,1965, pp. 277-353 [In Ukrainian].

3. Vyshenskyi I. Knyzhka (hl. 3) [Book]. Ukrainian literature of the XIV - XVI centuries. K.,1988. pp. 311-315 [In Ukrainian].

4. Vozniak M. Istoria ukrainskoi Literatury [History of Ukrainian Literature], Nr. 2, Lviv, 1994 [In Ukrainian].

5. Riezanov V. Drama ukrainska. Starovynnyi teatr ukrainskyi [Ukrainian drama. Vintage Ukrainian theater]. Nr. 1. K., 1926 [In Ukrainian]. 